Relating school leadership to perceived professional learning community characteristics: A multilevel analysis.

Bénédicte Vanblaere ${ }^{\mathrm{a}} \&$ Geert Devos ${ }^{\mathrm{a}}$

${ }^{\text {a }}$ Department of Educational Studies,

Ghent University,

Henri Dunantlaan 2,

9000 Ghent - Belgium

Benedicte.Vanblaere@UGent.be (corresponding author)

Geert.Devos@UGent.be

Disclaimer: Please note that this version may still slightly differ from the final print version. 


\section{Relating school leadership to perceived professional learning community characteristics: A multilevel analysis.}

This study examines the role of transformational and instructional school leadership in facilitating interpersonal professional learning community (PLC) characteristics (collective responsibility, deprivatized practice, and reflective dialogue). Survey data were collected in 48 Flemish (Belgian) primary schools from 495 experienced teachers. Multilevel analyses, when controlling for school characteristics, demonstrated that instructional leadership is related to perceived participation in deprivatized practice and participation in reflective dialogue. Transformational leadership matters for perceived participation in reflective dialogue but also for the presence of collective responsibility. These findings result in practical implications, based on the distinct merits of both leadership styles for interpersonal PLC characteristics.

Keywords: professional learning community (PLC); school leadership; multilevel analysis 


\section{Introduction}

There is an unprecedented international call for schools to be professional learning communities (PLCs) where teachers take responsibility for achieving high quality student learning and where teachers are willing to learn from other colleagues through systematic collaboration in order to achieve this goal (DuFour, 2004; McLaughlin \& Talbert, 2007; Stoll, Bolam, McMahon, Wallace, \& Thomas, 2006). PLCs are a powerful tool in our changing and increasingly complex world, where the quality of education relies heavily on teachers continuously renewing their professional knowledge and skills throughout their entire career (Darling-Hammond, Chung Wei, Alethea, Richardson, \& Orphanos, 2009). Furthermore, a vast amount of studies have demonstrated the contribution of PLCs to teacher learning, improved classroom instruction, and higher student achievement (Borko, 2004; Goddard, Goddard, \& Tschannen-Moran, 2007; Vandenberghe \& Kelchtermans, 2002). Hence, descriptions of what PLCs are and how schools function as PLCs, are abundant in the literature. As a result, PLC has become a buzz word over the last decades in both policy and research, making it a normative imperative towards schools (Cranston, 2009; Vescio, Ross, \& Adams, 2008). It is here that a problematic gap arises between the expectations in the academic world and the reality of day-to-day practices in many schools. Studies have shown that wide variation exists between schools regarding PLCs (Louis, Marks, \& Kruse, 1996) and that it is not self-evident for teachers to work collaboratively in their school and break through the reigning idea of teachers as strictly autonomous professionals within their classrooms (Day \& Sachs, 2004; Donaldson et al., 2008; OECD, 2014). Given the potential of PLCs, one must ask, how can teachers be stimulated to break through these barriers in order for schools to become strong PLCs?

Regarding the outcome variables, it is striking that the multidimensionality of PLCs has been widely recognized in literature (Bolam et al., 2005; Lomos, Hofman, \& Bosker, 
2011b; Sleegers, den Brok, Verbiest, Moolenaar, \& Daly, 2013), but that very few studies have taken separate characteristics into account when studying potential facilitating factors. Given the general fuzziness around the concept of PLCs, this results in considerable conceptual confusion about what is under examination and makes it difficult to draw clear conclusions or unambiguously interpret results (Vangrieken, Dochy, Raes, \& Kyndt, 2015). We believe that breaking down this concept into clear and identifiable characteristics largely increases the usefulness of the study for practice and theory because it provides information about how specific elements of PLCs can be encouraged. We address this lacuna by studying experienced teachers' perceptions of several interpersonal PLC characteristics as separate outcome variables. Our conception of the interpersonal PLC characteristics contains both behavioural and normative features (Bryk, Camburn, \& Louis, 1999), as shown below in Figure 1. We make a distinction between both, respectively studying the perceived frequency of individual teachers' participation in collaborative activities and the general perceived presence of certain norms and beliefs in the school.

With regards to the stimulating factors, research tells us that the importance of school leadership for the improvement of teaching cannot be underestimated. School leaders have a strong influence on their teachers and the learning environment in their school (Leithwood, Harris, \& Hopkins, 2008; Stoll et al., 2006). However, there is discord in the literature regarding what type of leadership is the most important in promoting strong PLCs. In general, especially the role of transformational leadership for PLCs has been widely recognized and researched (Hord, 1997; Olivier \& Hipp, 2010). Instructional leadership, on the other hand, is very relevant for student success (Robinson, Lloyd, \& Rowe, 2008), while research regarding the contribution to PLCs is more scarce and results in rather mixed findings (Andrews \& Lewis, 2002; McLaughlin \& Talbert, 2007). This leaves us wondering about which leadership style affects teachers' perceptions the most and thus contributes to supporting a strong PLC in 
schools. In this study, we contribute to untangling this matter by including experienced teachers' perceptions of both instructional and transformational leadership in the same model, with different interpersonal PLC characteristics as outcome variables. This approach allows the merits of both leadership styles to be uncovered for each interpersonal PLC characteristic separately and takes into account that the importance of a leadership style may vary depending on the characteristic. Furthermore, schools do not operate in a vacuum and a review study has shown that structural conditions of the school context can foster or impede strong collaborative environments (Stoll et al., 2006). Hence, we will control for several structural school characteristics in this study, because omitting these could influence our key findings regarding the relationship between school leadership and interpersonal PLC characteristics.

\section{Theoretical framework}

The theoretical framework we put forward in this study is visualised in Figure 1. The main study purpose is to identify how teachers' perception of school leadership is related to several perceived interpersonal PLC characteristics. In this regard, we incorporate two school leadership variables (instructional and transformational leadership) and three interpersonal PLC characteristics (collective responsibility, reflective dialogue, and deprivatized practice). In the following paragraphs, we will explain in depth the importance of each variable in this model. 


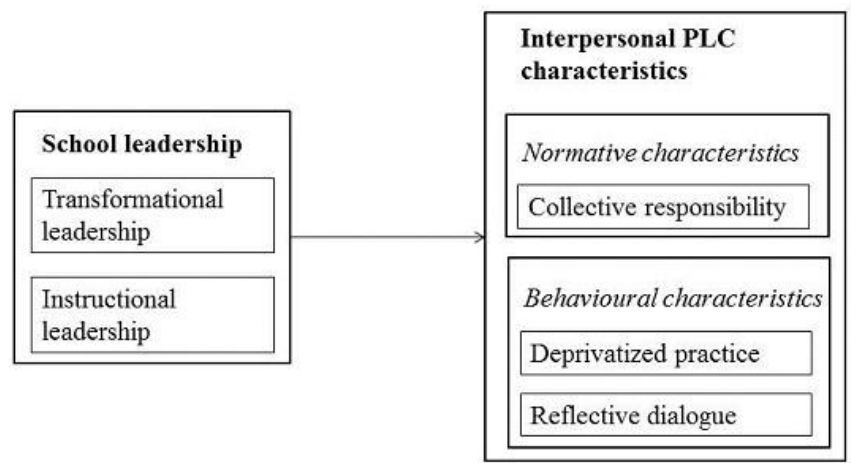

Figure 1 .

\subsection{Professional learning communities}

The concept of professional learning communities (PLCs) has gained considerable momentum over the past decades in literature concerning teacher learning (Vescio et al., 2008), since schools are increasingly seen as appropriate and desirable contexts for teachers' professional learning (Kwakman, 2003; Stoll \& Louis, 2007). The essence of schools functioning as PLCs lies in the collaborative work cultures for teachers where systematic collaboration and supportive interactions between teachers take place. Teachers engage in these activities from a critical point of view, with a focus on their own learning and the enhancement of their effectiveness as teachers. Hence, the ultimate goal is teaching all students in the best possible way (DuFour, 2004; Hord, 1997; Kwakman, 2003; Lomos, Hofman, \& Bosker, 2011a; Louis, Dretzke, \& Wahlstrom, 2010; Stoll et al., 2006; Vandenberghe \& Kelchtermans, 2002). This kind of collaborative environment has been identified as promising for improving the quality of teaching and for moving educational systems forward (Barth, 1990; Harris \& Muijs, 2005; Supovitz, Sirinides, \& May, 2009; Vandenberghe \& Kelchtermans, 2002; Vescio et al., 2008). For example, participation in PLCs has been linked to improvement in classroom practices (Goddard et al., 2007) and to an increased sense of work efficacy and in turn increased motivation and satisfaction (Louis \& Kruse, 1995). Equally, Little (2002) stated in her literature review that research findings agree 
on the important contribution of professional communities to instructional improvement and school reform.

\subsubsection{Dimensions of PLCs}

The PLC concept has previously been referred to as fuzzy (DuFour, 2004), due to a variety of definitions and the substantial differences in the comprehensiveness of operationalizing PLCs (Bolam \& McMahon, 2004; Lomos et al., 2011a). Sleegers et al. (2013) used the model of Mitchell and Sackney (2000) in an attempt to address this issue. The authors described the PLC concept as multidimensional, including organizational, personal, and interpersonal capacities. Firstly, organizational capacity includes supportive resources, structures, and systems, such as available time, information, and materials. It also encompasses cultural elements related to relationships and school climate (e.g. mutual trust, respect, networks, and partnerships) and stimulating and participative leadership. Secondly, personal capacity refers to teachers' active and reflective construction of knowledge, which implies examining and adapting teachers' cognitive structures and theories. In addition, the application of scientific knowledge and best practices is part of the personal capacity. Thirdly, interpersonal capacity contains behavioural elements such as shared practices between teachers, collaboration, reflective dialogues, and consultation between teachers. Shared beliefs, shared responsibility, and consensus also fall into this category and reflect more normative aspects. The organizational (Hord, 1997; Olivier \& Hipp, 2010; Visscher \& Witziers, 2004) and personal capacities (McLaughlin \& Talbert, 2001) are incorporated by some authors as sub-dimensions of PLCs, while a range of other scholars have chosen a more delineated concept and have focussed on the interpersonal characteristics, while seeing these other conditions as possible influences (DuFour, 2004; Wahlstrom \& Louis, 2008; Wiley, 2001). In this study, we follow the latter approach by focussing on several interpersonal PLC characteristics as outcome variables. This allows for a deeper investigation of the relationship between these features and 
some of the characteristics belonging to other dimensions, such as leadership. Earlier theoretical work that focussed on the interpersonal PLC characteristics has conceptually distinguished between behavioural (e.g. shared practices) and normative (e.g. shared vision on the role of teachers) features (Bryk et al., 1999; Verbiest, 2012).

\subsubsection{Behavioural features.}

The behavioural dimension refers to collaborative activities that occur between teachers. A first commonly identified characteristic of PLCs is reflective dialogue. Teachers who regularly engage in reflective and in-depth conversations about educational issues such as curriculum, instruction, and student development are essential in strong PLCs (A. Hargreaves, 2007; Wahlstrom \& Louis, 2008). These consultations are a way for teachers to gather new information about students, teaching, and learning (Hord, 1997; Visscher \& Witziers, 2004), but also to reflect upon their own practice (Bryk et al., 1999). A second behavioural characteristic comprises the deprivatization of teaching practices, where teachers make their teaching public and allow colleagues to enter their classroom. Teachers can share their practice with colleagues through strategies such as peer coaching, team teaching, and mutual observations (Hord, 1997; Kruse, Louis, \& Bryk, 1995; Louis et al., 1996; Wahlstrom \& Louis, 2008). Observing and providing feedback on each other's methods and practices can induce a deepened understanding of teaching and learning (Bryk et al., 1999).

\subsubsection{Normative features.}

A normative dimension underlies these collaborative behaviours. First, collective responsibility is central to a PLC. Teachers in strong PLCs do not consider school operations and improvement as a sole responsibility of the school principal, but collectively feel responsible in this regard (Stoll et al., 2006). This collective responsibility orients the focus of teachers on the learning of all students (A. Hargreaves, 2007), which creates a group incentive 
for all teachers to avoid teaching in isolation (DuFour, 2004; Newmann \& Wehlage, 1995; Stoll et al., 2006; Wahlstrom \& Louis, 2008). Second, shared values and vision are important in PLCs as they provide the basis for shared, collective, and ethical decision making, which is embodied in the language and actions undertaken in the classrooms (Kruse et al., 1995; Wahlstrom \& Louis, 2008). However, ambiguities arise in the literature about shared values and vision as a PLC characteristic. First, several researchers have considered a strong shared vision within a school as a supportive leadership practice (Fullan, 2006; Lomos, 2012; Northouse, 2007). This would imply that shared values have their place in the leadership dimension, belonging to the organizational capacity of PLCs, rather than to the interpersonal PLC characteristics. Second, some scholars emphasise the importance of a shared focus on improving student learning (Morrissey, 2000; Verbiest, 2012), which is closely related to what we defined here as collective responsibility. Bryk et al. (1999) elaborated on this matter and stated that a base of shared values focused on student learning could culminate in a sense of collective responsibility. Thus, the existence of collective responsibility in a school can signal that shared norms about learning and teaching are present and that they are embodied by the team. Hence, notwithstanding that shared values and vision are important in PLCs, it is unclear whether shared values and vision should be operationalized as a (separate) interpersonal PLC characteristic.

As a final note, it is important to mention that despite the broad support for the idea of schools functioning as PLCs, presenting an overly positive picture would be incorrect as several challenges arise in practice. Sharing and discussing practices and being collectively responsible contests the status quo in many schools, especially regarding deprivatized practice (OECD, 2014). Teachers' fear of change and the difficulties in moving away from norms such as isolation, seniority, and individualism, need to be recognized (Donaldson et al., 2008; McLaughlin \& Talbert, 2001; Zwart, Wubbels, Bergen, \& Bolhuis, 2009). 


\subsection{School leadership}

There is no doubt in the literature regarding the key role of school leaders in education. School leaders have a strong influence on their teachers and the working conditions in their schools, through which they can also contribute to student learning (Leithwood et al., 2008; Robinson et al., 2008; Stoll et al., 2006). As dynamism, energy, and commitment of the school leader are crucial for achieving positive working relations (Bolam et al., 2005; Elmore, 2000), it is not surprising that school leaders are expected to play a pivotal role in creating and sustaining PLCs (Gartner, 2010; Geijsel, Sleegers, Stoel, \& Krüger, 2009; Louis et al., 1996; Stoll et al., 2006). Northouse (2007), for example, defined leadership as a process whereby a group of individuals is influenced by a leader to achieve a common goal, while Elmore (2000) pointed to the responsibility of principals to unite teachers and to hold them accountable for their contributions to the collective result. A nuance regarding the role of school leadership is made by Stoll et al. (2006) who stated that principals can create conditions for a learning culture to develop and can stimulate it, but that they cannot ensure it will grow successfully. Two models in the field of educational school leadership are very influential and enduring, namely transformational and instructional leadership (Hallinger, 2003). However, these leadership models have a different conceptual focus.

\subsubsection{Transformational leadership.}

Transformational leadership is an empowering strategy that focusses on how leaders influence their staff. More specifically, transformational leaders are said to connect individual and collective action by not exercising power over people, but rather through them (Leithwood, 1992a). These leaders work through bottom-up participation and engage with teachers to raise their capacities and motivation to work towards improvement of the quality of teaching and instruction (Burns, 1978; Hallinger, 2003; Leithwood, Jantzi, \& Steinbach, 1999; Northouse, 2007). Three core dimensions of transformational leadership were identified by Bass (1985): 
vision building, providing individual support, and providing intellectual stimulation. More recently, four dimensions were added to the transformational leadership model of Bass (1985): modelling best practices, demonstrating high performance expectations, creating a productive school culture, and developing structures to foster teachers' participation (Leithwood \& Jantzi, 2000). Olivier and Hipp (2010) state that in strong PLCs, administrators generally employ this kind of motivation-oriented leadership and share power, authority, and decision-making. This is confirmed by Hord (1997), who indicated that the traditional idea of the omnipotent school leader has been replaced by more supportive and shared leadership structures in PLCs. Teachers in PLCs that are led by transformational leaders become actively engaged in activities such as planning, decision-making, professional development, and supervision of instruction (Marks \& Printy, 2003). Transformational leaders inspire their teachers and give them a greater sense of meaning, which contributes to transforming their school by developing teachers' capacity to work collaboratively to overcome challenges and reach commonly identified goals (Burns, 1978). Features of transformational leadership have explicitly been linked to interpersonal PLC characteristics in previous studies. For instance, the more teachers perceive their leader as exhibiting transformational characteristics, the more they will ask each other for feedback (Runhaar, Sanders, \& Yang, 2010). Furthermore, Geijsel et al. (2009) found evidence in primary schools of a significant relationship between how much intellectual stimulation school leaders provide and teachers' perceived professional collaboration, which includes elements related to reflective dialogue and deprivatized practice. Similarly, a series of bivariate correlations showed that transformational leadership in secondary schools is related to how teachers perceive their collaboration and community identity (Minckler, 2014). These studies show that school leaders can directly contribute to collaboration and community through adopting a transformational leadership style, which 
leads to the hypothesis that transformational leadership will be related to all three interpersonal PLC characteristics.

\subsubsection{Instructional leadership.}

On the other hand, instructional school leadership is commonly referred to in literature and is characterized by the direction of a leader's influence (Bush, 2014). Instructional leaders focus their interactions and work on the core business of education, namely teaching, learning, and classroom pedagogy (Hallinger, 2003; Louis et al., 2010). Instructional leaders typically focus on coordinating, monitoring, and evaluating curriculum; controlling instruction and assessment; and promoting a climate for learning (Marks \& Printy, 2003). Hence, this is a more directive form of leadership than transformational leadership. Scholars have pointed at two important aspects of instructional leadership that are necessary for school leaders to successfully engage in these school improvement functions. First, it is expected that leaders have sufficient knowledge of what is necessary for teachers to teach well (e.g. pedagogical knowledge and content knowledge) and that they understand the tenets of quality instruction (Marzano, Waters, \& McNulty, 2005; Spillane \& Louis, 2002; Wahlstrom \& Louis, 2008). Second, instructional leaders are presumed to provide active support for teachers, to interact with teachers, and to offer useful feedback that stimulates reflection (Colby, Bradshaw, \& Joyner, 2002; Louis et al., 2010). Several guidelines were issued by Leithwood (1992b) with regards to how instructional leaders can build and formulate their approach to teacher development. In relation to stimulating collegiality, the author emphasised that school leaders need to develop norms of reflection through the content and example of their own communication and teaching. This is complimentary to the finding that leaders can model particular behaviours and that what they do and say demonstrates what they value (Louis \& Kruse, 1995). Scholars do not always agree on the role of instructional leadership, however. In their study, McLaughlin and Talbert (2007) said that the role of school leaders needed to 
shift from a business manager to an instructional leader in order to stimulate PLCs in high schools. Contrarily, Andrews and Lewis (2002) focussed on the necessity of a strategic role for principals, involving overseeing projects at a distance and adopting a PR role. The pedagogical or instructional leadership role then becomes a responsibility of teachers and teacher leaders. Hence, literature is undecided about the role of instructional leadership for PLCs and, to our knowledge, no studies have focused solely on the role of instructional leadership for separate PLC characteristics, making specific relationships difficult to predict.

\subsubsection{Combining both leadership styles.}

Nevertheless, the different conceptual focus of both leadership models does not prevent them from being compatible. Theoretically, instructional and transformational leadership can function as a tandem and having a principal who combines both leads to high-quality pedagogy within schools (Marks \& Printy, 2003). If the organizational goals of a school are focused on learning, this facilitates a link between instructional and transformational goals (Bush, 2014). Several empirical studies about PLCs have examined teachers' perceptions of elements related to both leadership styles, but have focussed on a single outcome measure. Bryk et al. (1999), for example, found a positive significant effect of both supervision and facilitation by the school leader on PLC. A similar conclusion was reached by Louis et al. (2010) as both instructional and shared leadership were directly related to professional community. Other scholars have combined both leadership styles into one measure and have found that conversations about teaching and learning as well as deprivatized practice are fostered by leaders who are perceived as setting clear goals, encouraging trust and collaboration, and focusing on instructional improvement (Supovitz et al., 2009). However, studies that have analysed in depth how transformational and especially instructional leadership are related to several specific PLC characteristics are rare. This is an important issue because it can deepen our understanding of how school leadership and teacher 
collaboration interact with each other and it can orient more specifically how school leaders can be trained and supported in their practice. With this study we want to fill this research gap.

\subsection{Structural school context variables as control variables}

Previous studies have shown that structural school conditions can support the growth and development of PLCs (Bolam et al., 2005; Hord, 1997; Stoll et al., 2006). In this study, we therefore include three structural school context variables as control variables. A first characteristic that we incorporate because of its importance for the social dynamics within schools, is school size. Small sized schools encounter less internal communication difficulties, more opportunities for face-to-face interactions, and a stronger identification with the entire school community compared to larger schools (Southworth \& Weindling, 2002; Stoll et al., 2006). Notably, Bryk et al. (1999) found that small school size was a significant predictor for professional community, but that its significance disappeared once several human and social factors were added to the model. Next to school size, the school population or the particular mix of pupils has been linked to PLCs (McLaughlin \& Talbert, 1993; Stoll et al., 2006). Bolam et al. (2005) for instance found that the professional and pupil learning ethos in primary schools was inhibited by a high number of disadvantaged students in schools. A final school context characteristic is the difference between alternative and traditional schools. Alternative schools are based on the educational and pedagogical ideas from specific theorists, such as Steiner, Montessori, Dewey, and Freinet. Previous Flemish (Belgian) studies have established that a common denominator of alternative schools is that they are guided by very specific and pronounced educational principles and that they offer a different and often more innovative didactical and pedagogical learning environment than traditional schools (de Bilde, De Fraine, \& Van Damme, 2013; Department of Education, 2014; Eurydice, 2010; Verhaeghe \& Van Damme, 2005). Furthermore, an international study found evidence of a 
universal emphasis on community building, collaboration, and responsibility for the development of all students in alternative schools (Hazel \& Allen, 2013), while beginning teachers in Flemish alternative schools have been found to ask colleagues for help or feedback more often than teachers in traditional schools (De Neve \& Devos, 2015).

\section{Research design}

\subsection{Purpose of the study}

As shown in Figure 1, the present study was designed to explore the relationship between teachers' perception of instructional and transformational school leadership and three interpersonal PLC characteristics (i.e. collective responsibility, deprivatized practice, and reflective dialogue). In assessing this relationship, this study took both the individual teacher level and the school level into account. Furthermore, we controlled for several structural school characteristics (i.e. school size, school population, and alternative schools), allowing us to focus on the role of school leadership.

\subsection{Measures}

To answer this research question, a survey was conducted among experienced primary school teachers and information about the school context was obtained from the school leader and from government databases. All of the scales used in the questionnaire were based on existing instruments. A summary of the characteristics of the scales used to measure school leadership and interpersonal PLC characteristics can be found in the Appendix. This table presents the Cronbach's alpha, the range, and survey items per scale.

To measure the interpersonal PLC characteristics, we used the 'Professional Community Index' (Wahlstrom \& Louis, 2008). An extensive review by Lomos (2012) has identified this scale as a strong instrument, based on criteria such as a robust theoretical and empirical base, recentness, and multidimensionality. Originally, this scale consisted of four 
subscales: shared values, collective responsibility, deprivatized practice, and reflective dialogue. However, a validation by Lomos (2012) showed that a model including only collective responsibility, deprivatized practice, and reflective dialogue was necessary to reach a satisfactory model fit. We have come to a similar conclusion and did not retain the subscale of shared values in our analyses, based on theoretical and supplementary methodological motives. Ambiguities in the literature regarding shared values as a separate characteristic have been explained in the theoretical framework. Furthermore, as an initial confirmatory factor analysis showed an inadequate model fit, we performed an exploratory factor analysis (principal axis factoring, promax rotation), which showed the intertwinement of the shared values and collective responsibility scales and confirmed that removing the items related to shared values made the concept more robust. We also deleted an item regarding receiving meaningful feedback of the deprivatized practice scale, because of the relatedness to the reflective dialogue scale both conceptually and empirically. This item and the items of shared values are not included in the Appendix. To assess the validity of the scale with 11 observed values and three latent variables, we conducted a confirmatory factor analysis (Amos 22). We used four fit indicators. For the CFI and TLI a critical value of .90 is put forward for a reasonable fit, a fit larger than .95 is good (Hu \& Bentler, 1999; R. B. Kline, 1998); for the RMSEA and SRMR a fit between .06 and .08 is reasonable, a fit below .06 is good (Browne \& Cudeck, 1992; Hu \& Bentler, 1999). We allowed one pair of residuals of the reflective dialogue factor to correlate, based on conceptual relatedness (D. H. Hargreaves, 1995). We confirmed the three-factor structure with collective responsibility, reflective dialogue, and deprivatized practice as factors $\left(\chi^{2}=102.90, d f=40, p=.00 ; \mathrm{CFI}=.96\right.$; TLI=.95; RMSEA $=.05$ (.04-.07); SRMR=.05). The internal consistency of these three constructs (see Appendix) is acceptable according to P. Kline (1999). Related to the range of the scales, the scale for collective responsibility represents teachers' perceptions about the degree of prevalence of 
this characteristic in their school. The scales for deprivatized practice and reflective dialogue reflect the frequency of teachers' own engagement in these activities over the current school year.

We used existing scales to measure teachers' perceptions about the instructional leadership (Louis et al., 2010) and transformational leadership Hulpia, Devos, and Rosseel (2009) of their school leader. In the educational research field, as well as in broader literature, it is recognized that studying subordinates' perception of leadership generally provides more accurate ratings than leaders' self-ratings. For instance, self-ratings tend to be inflated and self-ratings are generally higher than ratings of subordinates (Atwater \& Yammarino, 1992). We slightly adjusted the instructional leadership scale of Louis et al. (2010) to fit the Flemish context by a priori deleting two items (items 4 and 7, p. 325). Item 4 referred to teacher planning meetings which are not know as such in Flanders, while item 7 appeared very confusing and unclear for teachers during the try-out of the questionnaire. Furthermore, the remaining five items for instructional leadership were all closely linked to the classroom practices of teachers, increasing the scale's conceptual consistency. A confirmatory factor analysis showed a reasonable fit for this two-construct model with instructional leadership and transformational leadership as factors $\left(\chi^{2}=384.33, d f=88, p=.00 ;\right.$ CFI=.95; TLI=.94; RMSEA=.08(.07-.09); SRMR=.07). The internal consistency of both scales is high, as shown in the Appendix.

\subsection{Procedure and participants}

Experienced teachers from 48 primary schools in Flanders (Belgium) were involved in this study. Similar to the Flemish school population, most of the schools in our sample offer education for children between 2.5 and 12 years old (ISCED 0 and 1). Two schools only provided ISCED 1, for children of ages 6 to 12. It is important to note that early childhood education (ISCED 0) is not compulsory in Flanders, but that $98.9 \%$ of all 3-4 year olds are 
enrolled, representing a very high participation rate (OECD, 2012). Flemish primary schools are in general run by one school leader. The schools were selected from the Flemish school population using stratified random sampling, taking into account the five geographical regions in Flanders and the denomination of the school (publicly financed schools run by the Flemish authority, publicly financed schools run by municipalities, and publicly financed schools privately run). As all schools are publicly financed, this implies that Flanders has no privately funded schools and that alternative schools are also publicly funded, drawing on the freedom of orientation which allows schools to freely choose their preferred teaching methods and vision. Alternative schools are overrepresented in the final sample (16\%) compared to the population (4\%), for which we controlled by including this variable as an explanatory variable in the research model (Centre for Multilevel Modelling, 2011). Furthermore, the sample contained 14 small schools ( $\leq 15$ staff members), 26 medium schools $(16 \leq$ staff members $\leq 30$ ), and 8 large schools (>30 staff members). We only took the number of pedagogical staff members into account in this classification. It should be noted that our sample only contained small and medium alternative schools as large alternative primary schools are rare. Moreover, schools in Flanders get extra teaching hours on top of their regular resources, for disadvantaged students with low socioeconomic profiles. Therefore, the ratio of extra hours compared to the total amount of teaching hours, provides an indication of a school's student population. The Flemish primary school population was divided into four quartiles based on this ratio. The sample contains 12 high SES schools, 14 moderately high SES schools, 10 moderately low SES schools, and 12 low SES schools. The alternative schools and school sizes were evenly distributed across these categories.

All schools included in this study had a minimum response rate of three teachers per school. In total, 495 teachers with six or more years of experience in their current school participated (Huberman, 1989), with an average of 10 teachers per school (70.6\% response 
rate). Regarding the teacher characteristics, Flemish primary schools generally employ teachers with bachelor degrees, which is reflected in our sample where $95 \%$ of teachers obtained a bachelor degree. The sample included 14\% male teachers and $86 \%$ female teachers. The majority of teachers $(69 \%)$ is involved in teaching ISCED 1. These characteristics are similar to the Flemish primary school teaching population, which makes us assume that the non-response is not systematic and that our sample reflects the intended research population of experienced primary school teachers. Teachers' average job experience was 20 years, ranging from 6 to 41 years, while the mean length in their current school was 16 years (6-38 years).

\subsection{Data analysis}

Our data had an inherent hierarchical structure as teachers were nested into schools. Because this violates the independence assumption of the data, multilevel analysis was needed (Hox, 2010). We conducted three separate multilevel regression analyses in MLwiN 2.29, each time using the teachers' perspective on one of the interpersonal PLC characteristics as a dependent variable. The variance at the school level in the null-models was significantly different from zero for all outcome variables. This indicates that there was systematic between-group variance and that teachers in the same school were more alike than teachers in different schools for the outcome variables, which provided further justification for the use of multilevel modelling techniques. The estimation procedure was iterative generalized least squares. For the two continuous independent variables regarding teachers' perception of school leadership, we applied grand mean centering. All structural school context variables were of a categorical nature. Alternative schools were indicated using a dummy-variable (0 for traditional schools, 1 for alternative). Regarding school size, we created a categorical variable ( 1 for small schools, 2 for medium schools, 3 for large schools). The categories for student population were based on student SES (1 for high SES students, 2 for moderately 
high, 3 for moderately low, 4 for low). For these categorical variables, we used the first category (small school and high SES students) as the reference category. The model for each outcome variable was fitted gradually. Initially, we added teacher level variables (model 1) as fixed effects to examine whether these were associated with the outcome variable. Then we added the school level control variables (model 2). Afterwards, we tested for random slope variance at the school level and the teacher level and added the significant random slopes in model 3 if applicable. The null hypothesis for these tests is that the slope coefficients for a predictor variable are the same for respectively all schools (school level) and for all teachers within one school (teacher level), as would be the case in an ordinary regression analysis, without the multilevel structure (Hox, 2010). In other words, the alternative hypothesis is that there are differences between schools or between teachers within schools in the extent to which an independent variable plays a role in explaining the dependent variable. For all significant variables in the final model, we reported an effect size based on the formula that Elliot and Sammons (2004) recommend for multilevel models.

\section{Results}

Our results demonstrate the important relationship between teachers' perceptions of school leadership and interpersonal PLC characteristics. While controlling for several structural school characteristics, we found differential relationships for instructional and transformational leadership, signifying that they both have a role to play and are complementary approaches for achieving high interpersonal PLC characteristics. In the following paragraphs, we will explain the results of our analyses more in depth.

\subsection{Descriptive statistics}

The descriptive statistics of experienced primary school teachers' perception of school leadership and interpersonal PLC characteristics are listed in Table 1. Teachers indicated that 
they had rarely engaged in the deprivatization of classroom practices during the current school year, while on the other hand, they had taken part in reflective dialogues every now and then. Furthermore, these teachers perceived a sense of collective responsibility in their school. Related to school leadership, teachers recognized frequent transformational and occasional instructional leadership in the behaviour of their school leader.

Table 1. Descriptive statistics of the measurement scales.

\begin{tabular}{llll}
\hline & $\boldsymbol{M}(\boldsymbol{S D})$ & Min & Max \\
\hline Professional learning community & & & \\
$\quad$ Collective responsibility & $3.68(.65)$ & 1.67 & 5.00 \\
$\quad$ Deprivatized practice & $1.87(.74)$ & 1.00 & 4.33 \\
$\quad$ Reflective dialogue & $3.29(.70)$ & 1.20 & 5.00 \\
Transformational leadership & $3.73(.81)$ & 1.30 & 5.00 \\
Instructional leadership & $2.89(.80)$ & 1.00 & 5.00 \\
\hline
\end{tabular}

$N($ teachers $)=495$ and $N($ schools $)=48$

Tables 2, 3, and 4 report on the results of the multilevel regression analyses with respect to collective responsibility, deprivatized practice, and reflective dialogue as dependent variables. From the results of the null-models, we calculated the variance partitioning component (intraclass correlation coefficient). This coefficient represents the proportion of the variance in the outcome variable that is explained by the clustering of teachers into schools. Thus, this indicates how much of the variance in these variables is attributable to differences between schools. These coefficients equal 16\%, 18\%, and $22 \%$ for respectively reflective dialogue, deprivatized practice, and collective responsibility.

\subsection{Collective responsibility}

As shown in Table 2, the results for Model 1 indicated that teachers' perception of school leaders' transformational leadership was significant for collective responsibility. Thus, the higher teachers assessed their school leader's transformational leadership, the more collective 
responsibility they experienced in the school. The results of Model 2 revealed that this relationship was not affected by including the school level control variables. Of the control variables, only alternative schools were significant, indicating that teachers in alternative schools experienced more collective responsibility in their schools than their colleagues in traditional schools. We tested for random slope variance at both the school level and the teacher level, but this was not significant.

\subsection{Deprivatized practice}

The results for Model 1 in Table 3 indicated that instructional school leadership was significant for deprivatized practice. Higher perceptions of instructional school leadership led to teachers reporting that they engaged in deprivatized practice more frequently. Adding the school level control variables (see Model 2) did not affect this relationship. Alternative school was again the only significant control variable once random slopes were added in Model 3. The variance of the regression slopes for instructional leadership was significant both at the school and teacher level. Thus, differences were noticeable between schools and between teachers within the same school in the extent to which instructional school leadership played a role in the reported frequency of deprivatized practice. This implies that we should not interpret the estimated regression coefficient (.261) for instructional school leadership without considering this variation. In an ordinary regression model, the regression coefficient means that when instructional leadership goes up by one, deprivatized practice goes up by .261, for all teachers in all schools. However, in this multilevel model, the regression coefficient for instructional leadership varies across the schools and across teachers within the same school and the regression coefficient is just the expected increase (the mean) across all teachers in all schools. Going even further, we can explore the pattern in the random slopes. As the random 
Table 2. Two-level multilevel analysis with collective responsibility as a dependent variable.

\begin{tabular}{|c|c|c|c|c|c|}
\hline Parameter & & Null-model & Model 1 & Model 2 & Effect size \\
\hline \multirow[t]{11}{*}{ Fixed } & Intercept & $3.705(.053)$ & $3.691(.041)$ & $3.689(.107)$ & \\
\hline & Teacher level variables - Level 1 & & & & \\
\hline & Transformational leadership & & $.241(.044)^{* * *}$ & $.237(.043) * * *$ & .696 \\
\hline & Instructional leadership & & $.072(.044)$ & $.073(.043)$ & \\
\hline & School level variables - Level 2 & & & & \\
\hline & Alternative school (vs. traditional school) & & & $.344(.110)^{* *}$ & .627 \\
\hline & Moderately high SES (vs. high SES) & & & $.052(.094)$ & \\
\hline & Moderately low SES (vs. high SES) & & & $.191(.101)$ & \\
\hline & Low SES (vs. high SES) & & & $.008(.096)$ & \\
\hline & $16-30$ teachers (vs. $\leq 15$ teachers) & & & $-.160(.093)$ & \\
\hline & $>30$ teachers $($ vs. $\leq 15$ teachers $)$ & & & $-.104(.110)$ & \\
\hline \multirow[t]{4}{*}{ Random } & Level 2-school & & & & \\
\hline & $\sigma_{\mu 0}^{2}$ & $.096(.027) * * *$ & $.046(.016)^{* *}$ & $.020(.010)$ & \\
\hline & Level 1-teachers & & & & \\
\hline & $\sigma_{\mathrm{e} 0}^{2}$ & $.325(.022) * * *$ & $.302(.020)^{* * *}$ & $.301(.020) * * *$ & \\
\hline \multirow[t]{3}{*}{ Model Fit } & Deviance & 912.500 & 848.689 & 827.900 & \\
\hline & $\chi^{2}$ & & $63.811 * * *$ & $20.789 * *$ & \\
\hline & Df & & 2 & 6 & \\
\hline
\end{tabular}


Table 3. Two-level multilevel analysis with deprivatized practice as a dependent variable.

\begin{tabular}{|c|c|c|c|c|c|c|}
\hline Parameter & & Null-model & Model 1 & Model 2 & Model 3 & Effect size \\
\hline \multirow[t]{11}{*}{ Fixed } & Intercept & $1.890(.056)$ & $1.876(.049)$ & $1.764(.139)$ & $1.776(.122)$ & \\
\hline & Teacher level variables - Level 1 & & & & & \\
\hline & Transformational leadership & & $-.013(.052)$ & $-.013(.051)$ & $.003(.046)$ & \\
\hline & Instructional leadership & & $.291(.052)^{* * *}$ & $.275(.052) * * *$ & $.261(.063)^{* * *}$ & .686 \\
\hline & School level variables - Level 2 & & & & & \\
\hline & Alternative school (vs. traditional school) & & & $.311(.142)^{*}$ & $.342(.135)^{*}$ & .559 \\
\hline & Moderately high SES (vs. high SES) & & & $.066(.123)$ & $.007(.106)$ & \\
\hline & Moderately low SES (vs. high SES) & & & $-.010(.133)$ & $-.092(.115)$ & \\
\hline & Low SES (vs. high SES) & & & $.260(.126)^{*}$ & $.160(.113)$ & \\
\hline & $16-30$ teachers $(v s . \leq 15$ teachers $)$ & & & $-.013(.121)$ & $.021(.107)$ & \\
\hline & $>30$ teachers $($ vs. $\leq 15$ teachers $)$ & & & $-.036(.146)$ & $-.050(.122)$ & \\
\hline \multirow[t]{5}{*}{ Random } & Level 2-school & & & & & \\
\hline & $\sigma_{\mu 0}^{2}$ & $.098(.030)^{* * *}$ & $.069(.023) * *$ & $.045(.018)^{*}$ & $.025(.015)$ & \\
\hline & $\begin{array}{l}\sigma_{\text {instructional leadership }}^{2} \\
\text { Level 1-teachers }\end{array}$ & & & & $.058(.028)^{*}$ & \\
\hline & $\sigma_{\mathrm{e} 0}^{2}$ & $.441(.029) * * *$ & $.414(.028) * * *$ & $.414(.028) * * *$ & $.374(.033)^{* * *}$ & \\
\hline & $\sigma_{\mathrm{e} 0 \text {.instructional leadership }}$ & & & & $.048(.020)^{*}$ & \\
\hline \multirow[t]{3}{*}{ Model Fit } & Deviance & 1054.362 & 1006.493 & 994.839 & 976.876 & \\
\hline & $\chi^{2}$ & & $47.869 * * *$ & 11.654 & $17.963 * * *$ & \\
\hline & Df & & 2 & 6 & 2 & \\
\hline
\end{tabular}


Table 4. Two-level multilevel analysis with reflective dialogue as a dependent variable.

\begin{tabular}{|c|c|c|c|c|c|c|}
\hline Parameter & & Null-model & Model 1 & Model 2 & Model 3 & Effect size \\
\hline \multirow[t]{11}{*}{ Fixed } & Intercept & $3.307(.051)$ & $3.295(.042)$ & $3.331(.118)$ & $3.336(.116)$ & \\
\hline & Teacher level variables - Level 1 & & & & & \\
\hline & Transformational leadership & & $.101(.049)^{*}$ & $.096(.048)^{*}$ & $.122(.060)^{*}$ & .323 \\
\hline & Instructional leadership & & $.231(.049)^{* * *}$ & $.211(.049)^{* * *}$ & $.225(.046)^{* * *}$ & .594 \\
\hline & School level variables - Level 2 & & & & & \\
\hline & Alternative school (vs. traditional school) & & & $.285(.120)^{*}$ & $.298(.118)^{*}$ & .489 \\
\hline & Moderately high SES (vs. high SES) & & & $-.118(.103)$ & -.146.099) & \\
\hline & Moderately low SES (vs. high SES) & & & $.025(.110)$ & $-.054(.106)$ & \\
\hline & Low SES (vs. high SES) & & & $.111(.104)$ & $.075(.101)$ & \\
\hline & $16-30$ teachers $(\mathrm{vs} . \leq 15$ teachers $)$ & & & $-.128(.102)$ & $-.137(.100)$ & \\
\hline & $>30$ teachers $($ vs. $\leq 15$ teachers $)$ & & & $-.029(.120)$ & $-.023(.117)$ & \\
\hline \multirow[t]{5}{*}{ Random } & Level 2-school & & & & & \\
\hline & $\sigma_{\mu 0}^{2}$ & $.081(.026)^{* * *}$ & $.041(.017)^{*}$ & $.021(.012)$ & $.013(.012)$ & \\
\hline & $\begin{array}{l}\sigma_{\text {transformational leadership }}^{2} \\
\text { Level 1-teachers }\end{array}$ & & & & $.052(.026)^{*}$ & \\
\hline & $\sigma_{\mathrm{e} 0}^{2}$ & $.417(.028) * * *$ & $.388(.026)^{* * *}$ & $.387(.026)^{* * *}$ & $.371(.033)^{* * *}$ & \\
\hline & $\sigma_{\mathrm{e} 0 \text {.transformational leadership }}$ & & & & $-.053(.017) * *$ & \\
\hline \multirow[t]{3}{*}{ Model Fit } & Deviance & 1022.134 & 962.569 & 947.606 & 931.290 & \\
\hline & $\chi^{2}$ & & $59.565 * * *$ & $14.963 * *$ & $16.316^{* * *}$ & \\
\hline & Df & & 2 & 6 & 2 & \\
\hline
\end{tabular}


variance at the school level was positive, graphically representing the slope for each school with instructional leadership on the $\mathrm{x}$-axis and deprivatized practice on the y-axis, would show a pattern of lines fanning out. Hence, schools were more similar regarding deprivatized practice for low values of instructional leadership, while differences between schools were larger for high values of instructional leadership. Mathematically, differences in scores for deprivatized practice increased between schools as the scores for instructional leadership increased. The random variance at the teacher level was also positive, thus a graphical representation of the slopes for teachers within schools would also show a pattern of fanning

out. Teachers' scores for deprivatized practice within the same school were more similar for low instructional leadership, while differences increased as instructional leadership was scored higher.

\subsection{Reflective dialogue}

Model 1 regarding reflective dialogue showed that both types of school leadership were significantly related to the frequency of reflective dialogue (see Table 4). As teachers perceived higher instructional and transformational school leadership, the reported frequency of their engagement in reflective dialogue was higher. However, effect sizes in the final model showed that instructional leadership had a notably larger impact than transformational leadership. Again, adding the control variables did not change these relationships (Model 2) and teachers in alternative schools were found to have significantly more frequent reflective dialogues than their counterparts in traditional schools. Keeping in mind that instructional school leadership was the strongest predictor, the variance of the regression slopes for transformational leadership was significant at both the school and teacher level. Hence, this points at differences between schools and between teachers within the same school in the extent to which transformational leadership played a role in the reported frequency of reflective dialogue. More specifically, at the school level, the positive slope variance signified 
that the differences in scores regarding reflective dialogue between schools increased as transformational leadership increased. Therefore, the higher teachers judged their leaders' transformational leadership, the more differences occurred between schools regarding the frequency of reflective dialogue while scores between schools were more similar for low transformational leadership. Contrarily, the negative slope covariance at the teacher level showed the inverse pattern. In a graphical representation, representing the slope for each teacher within one school with instructional leadership on the x-axis and reflective dialogue on the y-axis, would show a pattern of lines fanning in. Mathematically, differences between teachers within the same school regarding reflective dialogue decreased as the transformational leadership was scored higher. Thus, the more transformational leadership teachers within the same school perceived, the closer their scores were regarding reflective dialogue, and the less transformational school leadership, the more diverse their scores were.

\section{Discussion}

PLCs and their interpersonal characteristics are a hot item in the educational literature. As PLCs are seen as promising contexts for teachers' continuous professional development, it is highly relevant to study how school leaders can facilitate PLC characteristics in their schools. In this study, we focused on two leadership styles: instructional and transformational leadership, while incorporating several structural school variables as control variables. The current study adds to existing literature by assessing the relationship between school leadership and three separate perceived interpersonal PLC characteristics. This results in a more profound insight into how instructional and transformation leadership and learning communities are intertwined. We found that how teachers perceived the instructional leadership in their school was related to their participation in deprivatized practice and participation in reflective dialogue and that teachers' perceptions of transformational leadership was associated with participation in reflective dialogue and the presence of 
collective responsibility. We found two significant random slopes at the school and teacher level. We can draw several conclusions from these results.

A first conclusion concerns the presence of interpersonal PLC characteristics in primary schools. Experienced teachers in our sample had the highest perceptions regarding the presence of collective responsibility in their school. This is a promising finding as it shows that the norm of strict individual teacher responsibility within their classroom is giving way to a more collective norm in Flemish primary schools. However, studies have shown that it is not easy for teachers in schools worldwide to achieve collaborative school environments such as PLCs (Donaldson et al., 2008; OECD, 2014). In our study, this was the most outspoken for deprivatized practice, as teachers indicated that they rarely engaged in deprivatized practice. This is in line with several other international studies that found that teachers hardly open up the doors of their classrooms for each other (Lomos et al., 2011b; OECD, 2014). In contrast, teachers in our study did report to have engaged in reflective dialogues every now and then. This provides support for Day and Sachs (2004) when they state that most teachers work in isolation from their colleagues when it comes down to examining and sharing practice itself, and that collaboration is mostly situated at the level of talking about teaching. In this respect, it is possible that practical constraints prevent teachers from actively observing their colleagues, but that they compensate by talking about their classroom experiences or other educational matters (Zwart et al., 2009). Furthermore, the intraclass correlation coefficients of the interpersonal PLC characteristics indicated that between $16 \%$ and $22 \%$ of the variation in teachers' PLC scores was attributable to the group effect from belonging to a particular school. These coefficients can be considered as high, since they usually vary between .05 and .25 in social sciences (Snijders \& Bosker, 2012). It is not unexpected, however, that teachers within the same schools have rather similar perceptions of the interpersonal PLC characteristics as these characteristics refer to specific 
interactions in which teachers engage and to a feeling of collective responsibility among teachers in a school. Nevertheless, a substantial amount of the variation between teachers' scores remained at the teacher level. This underlines the importance of individual teachers' perceptions and actions (Kelchtermans, 1994) and supports the statement of Stoll et al. (2006) that it depends greatly on the individual how PLCs are perceived and shaped.

Second, the descriptive results regarding school leadership indicated that teachers mainly perceived their school leader as a transformational leader who frequently exhibits behaviours such as having and building a strong vision, being available, stimulating professional development, motivating and supporting teachers, and providing support for collaboration. In addition, teachers also noticed that their school leader was concerned with instructional issues and interacted with staff members about these matters every now and then, thus exercising instructional leadership from time to time.

A third conclusion was that these two styles of school leadership were related to overlapping, but also different kinds of interpersonal PLC outcomes, based on teacher selfreport. Related to collective responsibility, we found that the higher teachers assessed the transformational leadership of their principal, the more collective responsibility they perceived in their school. Hence, leaders who focus their work on motivating their teachers and raising their capacities, seem to at least partially accomplish this goal because teachers feel more responsible to collectively work towards improving instruction. This collective responsibility is an essential characteristic of PLCs as it ensures that teachers adopt a broader perspective regarding their responsibilities within the school. As long as teachers are not concerned with each other's teaching and resulting student learning, little incentive is given to engage in meaningful collaborative behaviours (A. Hargreaves, 2007; Newmann \& Wehlage, 1995). Furthermore, it has been suggested that raising shared responsibility through adopting a transformational leadership style, can benefit the success of the entire school organisation 
(Leithwood, Menzies, Jantzi, \& Leithwood, 1999). Hence, future studies could investigate the relationships between leadership, collective responsibility, collaboration, and student achievement.

Regarding the behavioural interpersonal PLC features, the results indicated that especially instructional leadership had a large role to play, as it was a significant predictor for both deprivatized practice and reflective dialogue, while transformational leadership was only significant for reflective dialogue. As for deprivatized practice, we found that when teachers perceived high instructional leadership, they mentioned more frequent participation in deprivatized practice. Pointing out the stimulating role instructional leaders can play here is useful, as deprivatized practice has been previously found to occur infrequently around the globe (OECD, 2014). An essential feature of instructional leadership is the focus on instruction, learning, and pedagogy. It is therefore not surprising that leaders who explicitly pay attention to and interact with their teachers about these matters, encourage their teachers to do the same. This finding is also in line with the idea that leaders can model particular behaviour. Instructional leaders can for instance observe classroom practices and discuss them with the teacher involved afterwards. On the one hand, this demonstrates what they value as a school leader (Leithwood, 1992b; Louis \& Kruse, 1995), but on the other hand also familiarises teachers with the idea of opening up their classroom doors. It can be expected that when teachers are accustomed to regular classroom visits by the school leader, they will be less resistant towards the idea of sharing their classroom practices with their fellow teachers.

As for reflective dialogue, both transformational and instructional leadership were significant. Based on the effect sizes of transformational and instructional leadership, instructional leadership played a more important role than transformational leadership. Hence, by following-up on teachers and keeping a focus on instruction as a school leader, teachers were challenged and stimulated to discuss educational matters among themselves. Our results 
suggest that if school leaders act as instructional leaders and model a focus on the core business of teaching, teachers are continuously stimulated to rethink their teaching practices in collaboration with other teachers. Furthermore, a facilitative transformational leadership style also encouraged frequent reflective dialogues. This supports the general idea that transformational school leaders can create a learning organization and can stimulate teachers to innovate and take risks (Bryk et al., 1999). As a result, we suggest that being involved with teachers and paying attention to teaching and learning in these interactions with teachers, are both key features of school leadership for increasing interpersonal PLC characteristics.

Fourth, we found several significant random slopes for the leadership variables at the school and teacher level in our study. This illustrates what Bolam et al. (2005) had noticed in their case studies, namely that the effectiveness of leadership for PLCs can vary between schools and even within the same school between teachers. Looking at differences between schools, we found that the relationship between transformational leadership and reflective dialogue was not the same for all schools. The same was true between schools for instructional leadership and the frequency of deprivatized practice. In future studies, it could be worthwhile to investigate how different school level variables relate to deprivatized practice and reflective dialogue and explore which of these variables can explain the variation of the slopes for leadership and thus explain the different relationships in different schools. Regarding the variance between teachers within schools, the results showed a random slope for the relationship between instructional leadership and deprivatized practice and for the relationship between transformational leadership and reflective dialogue. Hence, a similar question for future research can be put forward here, namely why these relationships differ between teachers in one school. For instance, why is high instructional leadership associated with high deprivatized practice for some teachers in a school, but not for all teachers in a similar manner? As a result, attention towards the individual teachers' characteristics and 
ideas is inevitable in explaining differences in these relationships. The study of Donaldson et al. (2008) can provide inspiration here as they point to the importance of teachers' ideas regarding autonomy in their classrooms, egalitarianism, and seniority. It is noteworthy that teachers' perceptions of reflective dialogue became more similar between teachers in schools for high transformational leadership. This underlines the importance of transformational leadership in reducing differences in teachers' reported frequency of reflective dialogue between teachers within the same school. This shows that high transformational leadership can contribute to consensus between teachers about the frequency of reflective dialogue and can help to get all teachers on the same page regarding this matter.

A final conclusion relates to the control variables in this study. It was surprising that the distinction between traditional and alternative schools was the only significant control variable in the three models presented in this study. More specifically, teachers in alternative schools perceived more collective responsibility in their schools and reported that they engaged in reflective dialogues and deprivatized practice more frequently than teachers in traditional schools. The results prompt questions about which features of alternative schools could account for these relationships. Characteristics commonly associated with alternative schools, such as the strong belief in the school's pedagogy, the focus on community building, and the centrality of student learning in the school, could be worth investigating further in larger samples of alternative schools. Distinctions between different types of alternative schools could also be taken into account. As strong interpersonal PLC characteristics are considered a goal for all schools, an extended understanding of these relationships can facilitate alternative schools functioning as examples of good practices and thus inspire school leaders and teachers from traditional schools. 


\section{Conclusion}

Our study is subject to certain limitations and leads to several suggestions for future research to extend the findings in this study. First, we selected three interpersonal PLC characteristics (i.e. collective responsibility, deprivatized practice, and reflective dialogue) in this study. Our results should therefore not be generalized to PLCs in general, but rather be interpreted in relation to the specific characteristics that were under investigation. A second limitation of this study concerns the self-reported measures that were used. This implies that we can only speak of teachers' perception of collective responsibility in their school, perception of their participation in reflective dialogue and deprivatized practice, and their perception of school leadership. However, by using multilevel analysis techniques, we were able to partly transcend this individual level by taking into account similarities between perceptions of teachers within the same school. Future studies could consider a qualitative research stance to document the interpersonal PLC characteristics in schools, using for example observations, interviews, or logs. Quantitative studies with sufficiently large sample sizes at the school level could combine the perceptions of all teachers in a school into an aggregate. Equally, they could also balance the advantages and disadvantages of using multivariate multilevel analysis techniques when examining PLC characteristics. These techniques have the advantage of taking the correlations between the three outcomes characteristics into account but are very complex on the other hand and require large sample sizes to limit statistical errors. Furthermore, the cross sectional nature of our study did not allow us to draw causal conclusions. This should be kept in mind when interpreting the results. Third, the variables used in this study were focused on leadership and structural school characteristics. Therefore, individual teacher variables such as job experience, self-efficacy or teachers' beliefs regarding collaborative work environments, could be considered for inclusion in a more comprehensive model. Also, we did not investigate structural school variables directly related to 
collaboration, such as the time and space provided for collaborative activities (Stoll et al., 2006), which could be included in future research.

This study has several implications for the practice of school leaders. In the context of interpersonal PLC characteristics, the results of this research have confirmed the importance of teachers' perception of instructional and transformational leadership. We found differential relationships for the two leadership styles, signifying that they both have a role to play and are complementary approaches for achieving high interpersonal PLC characteristics. As a result, we consider a combination of leadership styles of the utmost importance. Thus, we can suggest that school leaders should be deeply involved with teachers' classroom practices and provide them with suggestions or guidance as an instructional leader. Next to that, they should pay sufficient attention to their transformational role of supporting and encouraging teachers. Hence, this study also has implications for the professional development of school leaders. Professional development related to the transformational leadership aspect could be directed towards mastering how to coach and motivate teachers, which can be difficult to learn because it deals with awareness, attitudes, and personal styles. Additionally, school leaders might need assistance in gaining sufficient educational knowledge and background to enable them to act as a strong educational leader. Moreover, attention could be paid to setting priorities in school leaders' use of time and balancing the more instruction-oriented leadership style that underlies instructional leadership, and the more people-oriented style of transformational leadership. Nevertheless, it can be challenging for one school leader to combine both as they have a different conceptual focus (Shatzer, Caldarella, Hallam, \& Brown, 2014). In this regard, we believe in the possibility of distributed leadership, provided that two considerations are taken into account. First, it can be difficult for a school leader to be equipped with sufficient pedagogical content knowledge to provide high quality instructional leadership on all areas and grades. Hence, leadership around 
instructional matters can become a shared endeavour with teacher leaders or other members of the leadership team in larger schools (Marks \& Printy, 2003). As such, selection of members of this leadership team could also depend on the complementarity of the candidate's profile with the strengths and weaknesses of the current team or school leader. However, the nature of transformational leadership makes it obvious that this type of leadership should remain with the main school leader. Transformational leadership involves the creation of a kind of norm for the entire school that requires all stakeholders to be on the same page. It is important that this originates from the top and consequently permeates all levels of the school. A second point of reflection is that the success of distributing these leadership tasks is likely to depend greatly on cooperation between the leaders, including characteristics such as openness, mutual trust, and communication (Kozlowski \& Ilgen, 2006).

In conclusion, this study contributes to the knowledge about teachers' perceptions of three core interpersonal PLC characteristics: collective responsibility, reflective dialogue, and deprivatized practice. While controlling for several structural school variables, the results showed that whether teachers perceived transformational and instructional leadership behaviours in their principal was a critical facilitating factor for their scores on the interpersonal PLC characteristics. More specifically, perceived instructional leadership was related to participation in deprivatized practice and participation in reflective dialogue. Teachers' perceptions of transformational leadership, on the other hand, were associated with participation in reflective dialogue and the presence of collective responsibility.

\section{References}

Andrews, D., \& Lewis, M. (2002). The experiences of a professional community: Teachers developing a new image of themselves and their workplace. Educational Research, 44(3), 237-254. doi:10.1080/00131880210135340

Atwater, L. E., \& Yammarino, F. J. (1992). Does self-other agreement on leadership perceptions moderate the validity of leadership and performance predictions. . Personnel Psychology, 45(1), 141-164. doi:10.1111/j.1744-6570.1992.tb00848.x 
Barth, R. S. (1990). Improving schools from within: Teachers, parents, and principals can make the difference. San Francisco, CA: Jossey-Bass.

Bass, B. M. (1985). Leadership and performance beyond expectations. New York, NY: Free Press.

Bolam, R., \& McMahon, A. (2004). Literature, definitions, and models: Towards a conceptual map. In C. Day \& J. Sachs (Eds.), International Handbook on the Continuing Professional Development of Teachers (pp. 33-63). Berkshire: Open University Press.

Bolam, R., McMahon, A., Stoll, L., Thomas, S., Wallace, M., Greenwood, A., . . . Smith, M. (2005). Creating and sustaining effective professional learning communities. London: DfES and University of Bristol.

Borko, H. (2004). Professional development and teacher learning: Mapping the terrain. Educational Researcher, 33(8), 3-15. doi:10.3102/0013189X033008003

Browne, M. W., \& Cudeck, R. (1992). Alternative ways of assessing model fit. Sociological Methods \& Research, 21(2), 230-258. doi:10.1177/0049124192021002005

Bryk, A. S., Camburn, E., \& Louis, K. S. (1999). Professional community in Chicago elementary schools: Facilitating factors and organizational consequences. Educational Administration Quarterly, 35(5), 751-781. doi:10.1177/0013161X99355004

Burns, J. M. (1978). Leadership. New York: Harper and Row.

Bush, T. (2014). Instructional and transformational leadership: Alternative and complementary models? Educational Management Administration \& Leadership, 42(4), 443-444. doi:10.1177/1741143214526830

Centre for Multilevel Modelling. (2011). Weighting in MLwiN. Bristol: University of Bristol.

Colby, S. A., Bradshaw, L. K., \& Joyner, R. L. (2002). Teacher evaluation: A review of the literature. Paper presented at the Annual Meeting of the American Educational Research Association, New Orleans, LA.

Cranston, J. (2009). Holding the reins of the professional learning community: Eight themes from research on principals' perceptions of professional learning communities. Canadian Journal of Educational Administration and Policy, 90(1), 1-22.

Darling-Hammond, L., Chung Wei, R., Alethea, A., Richardson, N., \& Orphanos, S. (2009). Professional learning in the learning profession: A status report on teacher development in the United States and abroad. Stanford, CA: National Staff Development Council and The School Redesign Network.

Day, C., \& Sachs, J. (2004). Professionalism, performativity, and empowerment: Discourses in the politics, policies, and purposes of continuing professional development. In $\mathrm{C}$. Day \& J. Sachs (Eds.), International Handbook on the Continuing Professional Development of Teachers (pp. 3-32). Berkshire: Open University Press.

de Bilde, J., De Fraine, B., \& Van Damme, J. (2013). Methodescholen in het Vlaamse basisonderwijs: Een overzicht van onderzoek naar de werking en effecten van methodescholen op basis van SIBO [Alternative education in Flemish primary education: An overview of research on the functioning and effects of alternative education based on SIBO]. Leuven: KULeuven.

De Neve, D., \& Devos, G. (2015). The role of environmental factors in beginning teachers' professional learning related to differentiated instruction. School Effectiveness and School Improvement, 1-23. doi:10.1080/09243453.2015.1122637

Department of Education. (2014). Methodescholen [Alternative education]. Retrieved from http://www.vlaanderen.be/nl/onderwijs-en-wetenschap/onderwijsaanbod/scholen-enopleidingen/methodescholen

Donaldson, M. L., Johnson, S. M., Kirkpatrick, C., Marinell, W., Steele, J., \& Szczesiul, S. (2008). Angling for access, bartering for change: How second stage teachers 
experience differentiated roles in schools. Teachers College Record, 110(5), 10881114.

DuFour, R. (2004). What is a "professional learning community"? Educational Leadership, 61(8), 6-11.

Elliot, K., \& Sammons, P. (2004). Exploring the use of effect sizes to evaluate the impact of different influences on child outcomes: Possibilities and limitations. In I. Schager \& K. Elliot (Eds.), But what does it mean? The use of effect sizes in educational research. (pp. 6-24). London: National Foundation for Educational Research.

Elmore, R. F. (2000). Building a new structure of school leadership. Washington, DC: Albert Shanker Institute.

Eurydice. (2010). Flemish Eurydice report - Organisation of the educational system in the Flemish Community of Belgium 2010. Brussels: Department of Education and Training.

Fullan, M. (2006). Turnaround leadership. San Francisco, CA: Jossey-Bass.

Gartner, S. (2010). The importance of professional learning communities to improve classroom instruction. (Master of Science Degree in Education), Martin Luther College, New Ulm, MN.

Geijsel, F. P., Sleegers, P. J., Stoel, R. D., \& Krüger, M. L. (2009). The effect of teacher psychological and school organizational and leadership factors on teachers' professional learning in Dutch schools. The Elementary School Journal, 109(4), 406427. doi:10.1086/593940

Goddard, Y. L., Goddard, R. D., \& Tschannen-Moran, M. (2007). A theoretical and empirical investigation of teacher collaboration for school improvement and student achievement in public elementary schools. Teachers College Record, 109(4), 877-896.

Hallinger, P. (2003). Leading educational change: Reflections on the practice of instructional and transformational leadership. Cambridge Journal of Education, 33(3), 329-351. doi:10.1080/0305764032000122005

Hargreaves, A. (2007). Sustaining professional learning communities. In L. Stoll \& K. S. Louis (Eds.), Professional learning communities: Divergence, depth and dilemmas (pp. 181-195). Berkshire: Open University Press.

Hargreaves, D. H. (1995). School culture, school effectiveness, and school improvement. School Effectiveness and School Improvement, 6(1), 23-46. doi:10.1080/0924345950060102

Harris, A., \& Muijs, D. (2005). Improving schools through teacher leadership. Berkshire: McGraw-Hill Education.

Hazel, C. E., \& Allen, W. B. (2013). Creating inclusive communities through pedagogy at three elementary school. School Effectiveness and School Improvement, 24(3), 336356. doi:10.1080/09243453.2012.692696

Hord, S. M. (1997). Professional learning communities: Communities of continuous inquiry and improvement. Austin, TX: Southwest Educational Development Laboratory.

Hox, J. (2010). Multilevel analysis: Techniques and applications (2nd ed.). New York, NY: Routledge.

Hu, L., \& Bentler, P. M. (1999). Cutoff criteria for fit indexes in covaraince structure analysis: Conventional criteria versus new alternatives. Structural Equation Modeling, 6(1), 1-55. doi:10.1080/10705519909540118

Huberman, M. (1989). On teachers' careers: Once over lightly, with a broad brush. International Journal of Educational Research, 13(4), 347-362. doi:10.1016/08830355(89)90033-5 
Hulpia, H., Devos, G., \& Rosseel, Y. (2009). Development and validation of scores on the distributed leadership inventory. Educational and Psychological Measurement, 69(6), 1013-1034. doi:10.1177/0013164409344490

Kelchtermans, G. (1994). De professionele ontwikkeling van leerkrachten basisonderwijs vanuit het biografisch perspectief [Primary school teachers' professional development from a biographic perspective]. Leuven: Universitaire Pers Leuven.

Kline, P. (1999). The handbook of psychological testing (2nd ed.). London: Routledge.

Kline, R. B. (1998). Structural equation modeling. New York, NY: The Guilford Press.

Kozlowski, S. W. J., \& Ilgen, D. R. (2006). Enhancing the effectiveness of work groups and teams. Psychological Science in the Public Interest, 7(3), 77-124. doi:10.1111/j.15291006.2006.00030.x

Kruse, S., Louis, K. S., \& Bryk, A. S. (1995). An emerging framework for analyzing schoolbased professional community. In K. S. Louis, S. D. Kruse, \& Associates (Eds.), Professionalism and community: Perspectives on reforming urban schools. (pp. 2344). Thousand Oaks, CA: Corwin Press.

Kwakman, K. (2003). Factors affecting teachers' participation in professional learning activities. Teaching and Teacher Education, 19(2), 149-170. doi:10.1016/s0742051x(02)00101-4

Leithwood, K. (1992a). The move toward transformational leadership. Educational Leadership, 49(3), 8-12.

Leithwood, K. (1992b). The principal's role in teacher development. In M. Fullan \& A. Hargreaves (Eds.), Teacher development and educational change (pp. 86-103). London: Falmer Press.

Leithwood, K., Harris, A., \& Hopkins, A. (2008). Seven strong claims about successful school leadership. School Leadership \& Management, 28(1), 21-42. doi:10.1080/13632430701800060

Leithwood, K., \& Jantzi, D. (2000). The effects of transformational leadership on organizational conditions and student engagement with school. Journal of Educational Administration, 38(2), 112-129. doi:10.1108/09578230010320064

Leithwood, K., Jantzi, D., \& Steinbach, R. (1999). Changing leadership for changing times. Philadelphia, PA: Open University Press.

Leithwood, K., Menzies, T., Jantzi, D., \& Leithwood, J. (1999). Teacher burnout: A critical challenge for leaders of restructuring schools. In R. Vandenberghe \& M. Huberman (Eds.), Understanding and preventing teacher burnout. Cambridge: Cambridge University Press.

Little, J. W. (2002). Locating learning in teachers' communities of practice: Opening up problems of analysis in records of everyday work. Teaching and Teacher Education, 18(8), 917-946. doi:10.1016/S0742-051X(02)00052-5

Lomos, C. (2012). Professional community and student achievement. (Unpublished doctoral thesis), Rijksuniversiteit Groningen, Groningen.

Lomos, C., Hofman, R. H., \& Bosker, R. (2011a). Professional community and student achievement - A meta-analysis. School Effectiveness and School Improvement, 22(2), 121-148. doi:10.1080/09243453.2010.550467

Lomos, C., Hofman, R. H., \& Bosker, R. (2011b). The relationship between departments as professional communities and student achievement in secondary schools. Teaching and Teacher Education, 27(4), 722-731. doi:10.1016/j.tate.2010.12.003

Louis, K. S., Dretzke, B., \& Wahlstrom, K. (2010). How does leadership affect student achievement? Results from a national US survey. School Effectiveness and School Improvement, 21(3), 315-336. doi:10.1080/09243453.2010.486586 
Louis, K. S., \& Kruse, S. (1995). Professionalism and community: Perspectives on reforming urban schools. Thousand Oaks, CA: Corwin Press.

Louis, K. S., Marks, H. M., \& Kruse, S. (1996). Teachers' professional community in restructuring schools. American Educational Research Journal, 33(4), 757-798. doi:10.3102/00028312033004757

Marks, H. M., \& Printy, S. M. (2003). Principal leadership and school performance: An integration of transformational and instructional leadership. Educational Administration Quarterly, 39(3), 370-397. doi:10.1177/0013161x03253412

Marzano, R., Waters, T., \& McNulty, B. (2005). School leadership that works. Alexandria, VA: Association for Supervision and Curriculum Development.

McLaughlin, M. W., \& Talbert, J. E. (1993). Contexts that matter for teaching and learning: Strategic opportunities for meeting the nation's educational goals. Stanford, CA: Center for Research on the Context of Secondary School Teaching.

McLaughlin, M. W., \& Talbert, J. E. (2001). Professional communities and the work of high school teaching (2nd ed.). Chicago, IL: University of Chicago Press.

McLaughlin, M. W., \& Talbert, J. E. (2007). Building professional learning communities in high schools: Challenges and promising practices. In L. Stoll \& K. S. Louis (Eds.), Professional learning communities: Divergence, depth and dilemmas (pp. 151-165). Berkshire: Open University Press.

Minckler, C. H. (2014). School leadership that builds teacher social capital. Educational Management Administration \& Leadership, 42(5), 657-679. doi:10.1177/1741143213510502

Mitchell, C., \& Sackney, L. (2000). Profound improvement: Building capacity for a learning community. Lisse: Swets \& Zeitlinger.

Morrissey, M. S. (2000). Professional learning communities: An ongoing exploration. Austin, TX: Southwest Educational Development Laboratory.

Newmann, F. M., \& Wehlage, G. G. (1995). Successful school restructuring: A report to the public and educators by the center on organization and restructuring of schools. Madison, WI: CORS.

Northouse, P. (2007). Leadership: Theory and practice (4th ed.). Thousand Oaks, CA: SAGE. OECD. (2012). Education at a Glance 2012: OECD Indicators. Paris: OECD Publishing.

OECD. (2014). TALIS 2013 Results: An international perspective on teaching and learning. Paris: OECD Publishing.

Olivier, D. F., \& Hipp, K. K. (2010). Assessing and analyzing schools as professional learning communities. In K. K. Hipp \& J. B. Huffman (Eds.), Demystifying professional learning communities. School leadership at its best. (pp. 29-42). Lanham, MD: Rowman \& Littlefield.

Robinson, V. M. J., Lloyd, C. A., \& Rowe, K. J. (2008). The impact of leadership on student outcomes: An analysis of the differential effects of leadership types. Educational Administration Quarterly, 44(5), 635-674. doi:10.1177/0013161x08321509

Runhaar, P., Sanders, K., \& Yang, H. D. (2010). Stimulating teachers' reflection and feedback asking: An interplay of self-efficacy, learning goal orientation, and transformational leadership. Teaching and Teacher Education, 26(5), 1154-1161. doi:10.1016/j.tate.2010.02.011

Shatzer, R. H., Caldarella, P., Hallam, P. R., \& Brown, B. L. (2014). Comparing the effects of instructional and transformational leadership on student achievement: Implications for practice. Educational Management Administration \& Leadership, 42(4), 445-459. doi:10.1177/1741143213502192

Sleegers, P., den Brok, P., Verbiest, E., Moolenaar, N. M., \& Daly, A. J. (2013). Towards conceptual clarity: A multidimensional, multilevel model of professional learning 
communities in Dutch elementary schools. The Elementary School Journal, 114(1), 118-137. doi:10.1086/671063

Snijders, T., \& Bosker, R. (2012). Multilevel analysis: An introduction to basic and advanced multilevel modeling. (2nd ed.). London: Sage.

Southworth, G., \& Weindling, D. (2002). Leadership in large primary schools: A report for the Esmee Fairbaim Foundation. Reading: University of Reading School of Education.

Spillane, J. P., \& Louis, K. S. (2002). School improvement process and practices: Professional learning for building instructional capacity. In J. Murphy (Ed.), The educational leadership challenge: Redefining leadership for the 21st century (pp. 83104). Chicago, IL: University of Chicago Press.

Stoll, L., Bolam, R., McMahon, A., Wallace, M., \& Thomas, S. (2006). Professional learning communities: A review of the literature. Journal of Educational Change, 7(4), 221258. doi:10.1007/s10833-006-0001-8

Stoll, L., \& Louis, K. S. (2007). Professional learning communities: Divergence, depth, and dilemmas. Berkshire: Open University Press.

Supovitz, J., Sirinides, P., \& May, H. (2009). How principals and peers influence teaching and learning. Educational Administration Quarterly, 46(1), 31-56. doi:10.1177/1094670509353043

Vandenberghe, R., \& Kelchtermans, G. (2002). Leraren die leren om professioneel te blijven leren: Kanttekeningen over context [Teachers learning to keep learning professionally: Reflections on context]. Pedagogische Studiën, 79, 339-351.

Vangrieken, K., Dochy, F., Raes, E., \& Kyndt, E. (2015). Teacher collaboration: A systematic review. Educational Research Review, 15(1), 17-40. doi:10.1016/j.edurev.2015.04.002

Verbiest, E. (2012). Professionele leergemeenschappen - Een inleiding [Professional learning communities - An introduction]. Antwerp: Garant.

Verhaeghe, J. P., \& Van Damme, J. (2005). Methodescholen in Vlaanderen: Beginsituatie en leerresultaten in het eerste leerjaar [Alternative schools in Flanders: Starting position and learning gains in first grade]. Leuven: Steunpunt loopbanen doorheen onderwijs naar arbeidsmarkt.

Vescio, V., Ross, D., \& Adams, A. (2008). A review of research on the impact of professional learning communities on teaching practice and student learning. Teaching and Teacher Education, 24(1), 80-91. doi:10.1016/j.tate.2007.01.004

Visscher, A. J., \& Witziers, B. (2004). Subject departments as professional communities? British Educational Research Journal, 30(6), 786-801. doi:10.1080/0141192042000279503

Wahlstrom, K., \& Louis, K. S. (2008). How teachers experience principal leadership: The roles of professional community, trust, efficacy, and shared responsibility. Educational Administration Quarterly, 44(4), 458-496. doi:10.1177/0013161X08321502

Wiley, S. D. (2001). Contextual effects on student achievement: School leadership and professional community. Journal of Educational Change, 2(1), 1-33. doi:10.1023/A:1011505709050

Zwart, R. C., Wubbels, T., Bergen, T., \& Bolhuis, S. (2009). Which characteristics of a reciprocal peer coaching context affect teacher learning as perceived by teachers and their students? Journal of Teacher Education, 60(3), 243-257. doi: $10.1177 / 0022487109336968$ 


\section{Appendix}

\begin{tabular}{|c|c|c|c|}
\hline & $\alpha$ & Range & Survey items \\
\hline \multicolumn{4}{|l|}{$\begin{array}{l}\text { Professional } \\
\text { learning community }\end{array}$} \\
\hline \multirow[t]{4}{*}{$\begin{array}{l}\text { Collective } \\
\text { responsibility }\end{array}$} & \multirow[t]{4}{*}{.68} & $\begin{array}{l}\text { Strongly } \\
\text { disagree }(1)-\end{array}$ & $\begin{array}{l}\text { Teachers in this school feel responsible to help each other } \\
\text { improve their instruction. }\end{array}$ \\
\hline & & Strong agree (5) & Teachers in this school take responsibility for \\
\hline & & & improving the school outside their own class. \\
\hline & & & $\begin{array}{l}\text { Teachers in this school help maintain discipline in the entire } \\
\text { school, not just their classroom. }\end{array}$ \\
\hline \multirow[t]{3}{*}{ Deprivatized practice } & \multirow[t]{3}{*}{.74} & $\begin{array}{l}\text { Never (1) - Very } \\
\text { often (5) }\end{array}$ & $\begin{array}{l}\text { How often in this school year have you had colleagues observe } \\
\text { your classroom? }\end{array}$ \\
\hline & & & $\begin{array}{l}\text { How often in this school year have you invited someone in to } \\
\text { help teach your class(es)? }\end{array}$ \\
\hline & & & $\begin{array}{l}\text { How often in this school year have you visited other teachers' } \\
\text { classrooms to observe instruction? }\end{array}$ \\
\hline \multirow[t]{5}{*}{ Reflective dialogue } & \multirow[t]{5}{*}{.78} & $\begin{array}{l}\text { Never (1)- Very } \\
\text { often (5) }\end{array}$ & $\begin{array}{l}\text { How often in this school year have you exchanged suggestions } \\
\text { for curriculum materials with colleagues? }\end{array}$ \\
\hline & & & $\begin{array}{l}\text { How often in this school year have you had conversations with } \\
\text { colleagues about the goals of this school? }\end{array}$ \\
\hline & & & $\begin{array}{l}\text { How often in this school year have you had conversations with } \\
\text { colleagues about development of new curriculum? }\end{array}$ \\
\hline & & & $\begin{array}{l}\text { How often in this school year have you had conversations with } \\
\text { colleagues about managing classroom behavior? }\end{array}$ \\
\hline & & & $\begin{array}{l}\text { How often in this school year have you had conversations with } \\
\text { colleagues about what helps students learn best? }\end{array}$ \\
\hline \multirow{10}{*}{$\begin{array}{l}\text { Transformational } \\
\text { leadership }\end{array}$} & \multirow[t]{10}{*}{.94} & Never (1) - & My principal premises a long term vision. \\
\hline & & Always (5) & My principal debates the school vision. \\
\hline & & & My principal compliments teachers. \\
\hline & & & My principal helps teachers. \\
\hline & & & My principal explains his/her reason for criticism to teachers \\
\hline & & & $\begin{array}{l}\text { My principal is available after school to help teaches when } \\
\text { assistance is needed. }\end{array}$ \\
\hline & & & My principal looks out for the personal welfare of teachers. \\
\hline & & & $\begin{array}{l}\text { My principal encourages teachers to pursue their own goals for } \\
\text { professional learning. }\end{array}$ \\
\hline & & & $\begin{array}{l}\text { My principal encourages teachers to try new practices consistent } \\
\text { with their own interests. }\end{array}$ \\
\hline & & & $\begin{array}{l}\text { My principal provides organizational support for teacher } \\
\text { communication and collaboration. }\end{array}$ \\
\hline \multirow[t]{5}{*}{$\begin{array}{l}\text { Instructional } \\
\text { leadership }\end{array}$} & \multirow[t]{5}{*}{.89} & $\begin{array}{l}\text { Never (1)- } \\
\text { Always (5) }\end{array}$ & $\begin{array}{l}\text { My principal has given me specific ideas on how to improve my } \\
\text { instruction. }\end{array}$ \\
\hline & & & $\begin{array}{l}\text { My principal clearly defines standards for instructional } \\
\text { practices. }\end{array}$ \\
\hline & & & My principal discusses instructional issues with me. \\
\hline & & & My principal observes my classroom instruction. \\
\hline & & & $\begin{array}{l}\text { My principal makes suggestions to improve classroom } \\
\text { management. }\end{array}$ \\
\hline
\end{tabular}

